\title{
Todas las naciones han de oyrla: Bells in the Jesuit reducciones of Early Modern Paraguay
}

\author{
Jutta Toelle \\ Max Planck Institute for Empirical Aesthetics \\ jutta.toelle@aesthetics.mpg.de
}

\begin{abstract}
The essay focuses on the role of bells in the Jesuit reducciones. Within the contested sound world of the mission areas, bells played an important role as their sounds formed a sense of space, regulated social life, and established an audibility of time and order. Amongst all the other European sounds which Catholic missionaries had introduced by the seventeenth century — church songs, prayers in European languages, and instrumental music - bells functioned especially well as signals of the omnipotent and omnipresent Christian God and as instruments in the establishing of acoustic hegemony. Taking the Conquista espiritual by Antonio Ruiz de Montoya (1639) as its main source, the essay points to several references to bells, as objects of veneration, as part of a flexible material culture, and, most importantly, as weapons in the daily fight with non-Christians, the devil, and demons.
\end{abstract}

\section{Keywords}

bells - sounds - reducciones - Devil - material culture - Paracuaria/Paraguay - Antonio Ruiz de Montoya - Roque González de Santa Cruz - Anton Sepp

A bell, a well-known instrument made of metal, with which principally the faithful are congregated to participate in the mass, or to hear the 
canonical hours, and the divine offices; and for that reason they put them high into the towers, so that they can be heard by all. ${ }^{1}$

In his Tesoro de la lengua castellana o española from 1611, Sebastián de Covarrubias y Orozco (1539-1613) concentrates on a bell's most important functions in a Christian context: to call the faithful to church and to prayer. To achieve this, Covarrubias continues, the bells are hung within high towers "so that they can be heard by everybody." The same bold idea of signaling the Christian faith to all can be found in a famous Spanish medieval legend and chanson de geste, the Leyenda de la campana de Huesca. In a version by the playwright Lope de Vega (1562-1635), written in the first years of the seventeenth century and published in 1623 as La campana de Aragón, King Ramiro II (1086-1157) invites the most important nobles of his country to his palace (in order to kill them), using the pretext of a miraculous bell that he has commissioned "que se oyga en todo el mundo" (which is to be heard all around the world). Don Fortunio Liçana incredulously questions this, at which the king answers, "El Aleman, el Indio, el Scita, el Persa, el Chino, el de Etiopia, el de Polonia, y todas las naciones, han de oyrla, yo no soy Rey?"2 The whole world, thus, is not only called to hear the bell ring, but obliged to listen to it.

Of course it is not a specifically Iberian conviction to see bells as hegemonic instruments, as agents and emblems of power. ${ }^{3}$ All over the early modern world, their peals were amongst the sounds through which religious, social, and political authority was negotiated. However, King Ramiro's mentioning of "el Indio" amongst those who are called to listen (at least in Lope de Vega's version of the story) takes us into the context of the Catholic missions in Latin America.

1 "CAMPANA, instrumento conocido de metal, con que se congregan principalmente los fieles a oficiar, o a oyr las horas Canonicas, y los Oficios Divinos, y assi las ponen en lo alto de las torres, para que puedan ser oydas de todos." Sebastián de Covarrubias y Orozco, Tesoro de la lengua castellana o española (Madrid: Luis Sanchez, 1611), 182-83, available at http:// fondosdigitales.us.es/fondos/libros/765/402/tesoro-de-la-lengua-castellana-o-espanola/. This article retains archaic Spanish spelling. All translations are the author's unless otherwise specified.

2 Lope de Vega, La campana de Aragón (Madrid: Iuan Gonçalez, 1623), 234.

3 See Ali Asgar Alibhai, "The Reverberations of Santiago's Bells in Reconquista Spain," La Corónica 36, no. 2 (2008): 145-64. 
The European sounds which Catholic missionaries had introduced by the seventeenth century-church songs, prayers in European languages, instrumental music, and bells - worked in a variety of ways: as markers of spatial territories, as signals of the omnipotent and omnipresent Christian God, and as weapons in the daily fight with non-Christian humans, the devil, demons, and evil spirits. ${ }^{4}$ Within this contested sound world, bells, as "the artillery of the church,"5 played an important role. They provide an exceptionally good example of how sounds form a sense of space, regulate social life, and establish an audibility of time and order. ${ }^{6}$ As Richard Cullen Rath stated, oral cultures were worlds governed by face-to-face encounters, but bells transcended these borders, by substituting visibility with audibility and thus effectively enlarging closely-knit communities. ${ }^{7}$ The sounds of bells can ring somebody in, call all within earshot together, and create a communal soundscape.

This article seeks to show how bells in the early modern era were employed in the missionizing process as instruments of spiritual conquest and of acoustic hegemony. ${ }^{8}$ As the epitome of Christian sound, a consecrated bell had many functions, often listed in an inscription. ${ }^{9}$ The 1612 treatise by Angelo Rocca (1545-1620), De campanis commentarius, mentions their effects on demons, who will be terrified and routed. ${ }^{10}$

4 Guillermo Wilde, "Toward a Political Anthropology of Mission Sound: Paraguay in the $17^{\text {th }}$ and $18^{\text {th }}$ Centuries," Music and Politics 1, no. 2 (2007):1-29.

5 Heinrich Samson, Zur Geschichte und Symbolik der Glocken (Frankfurt: Foesser Nachf., 1897), 355 .

6 Alain Corbin, Les cloches de la terre: Paysage sonore et culture sensible dans les campagnes au XIX ${ }^{e}$ siècle (Paris: Albin Michel, 1994).

7 Richard Cullen Rath, How Early America Sounded (Ithaca: Cornell University Press, 2005), 52 .

8 I owe the introduction to bells as a fascinating research object to the workshop "For Whom the Bell Tolls: Sound, Time and Acoustic Communication in the Early Modern World" (Institute of Advanced Study, University of Konstanz, January 2015), organized by my colleague Jan-Friedrich Missfelder, whom I would like to thank.

9 For instance: "Laudo Deum verum, plebem voco, congrego clerum, defunctum ploro, nimbum fugo, festa decoro" (I praise the true God, call the people together, gather the clerics, mourn for the dead, dispel the tempest, adorn the feasts), quoted in Samson, "Zur Geschichte und Symbolik der Glocken," 347 .

10 "Ut ad sonum Campanae Christi fideles bonos consequantur effectus, malis omnibus propulsis et in fugam conversis": Angelo Rocca, De campanis commentarius (Rome: G. Facciotti, 1612), 42. Rocca then quotes the proceedings of a council in Cologne in 1536: "Ut Daemones tinnitu Campanarum, Christianos ad preces concitantium, terreantur" (ibid., 43). 
Hundreds of tales, legends, and stories are attached to bells in different regions of the world: hidden or submerged bells pealing, bells which refuse to ring in settings other than their home church, bells announcing someone's death or the election of a new pope without being pealed by anyone. ${ }^{11}$ In many tales, bells acquire anthropomorphic traits, receive names, and are treated as members of the community.

R. Murray Schafer's ideas about bells aptly lend themselves to the present discussion of bells as social objects in a mission context. Schafer, who famously introduced the concept of soundscape, quotes "the noise of war and the 'noise' of religion" as profound acoustic interruptions of the premodern rural soundscape. ${ }^{12}$ Bells - and this is their unique feature — can stand for both noises; their sounds can be perceived as combining war and religion, even at the same time. Schafer also applies another concept to bells: he sees the centripetal quality of a bell's sound - in that it "attracts and unifies the community in a social sense, just as it draws man and God together"13 — as equilibrated by its centrifugal power, frightening away supernatural forces like thunder, evil spirits, and demons. Bells in the Jesuit reducciones seem to be a perfect example of these features.

\section{The reducciones}

Since the expulsion of the Jesuits from the Spanish and Portuguese empires, a lot has been written on the subject of the reducciones; here, I will concentrate only on certain specific aspects.

When beginning a new mission settlement, the first thing for any missionary to do was to put up the insignia of Christianity: a cross and a bell erected on a small construction made using a yoke. Subsequently, cross, bell (later the bell tower or church), and devotional images became the most symbolically

11 Ernest Morris, Legends o' the Bells: Being a Collection of Legends, Traditions, Folk-tales, Myths, etc., Centered Around the Bells of All Lands (London: Sampson Low, Marston \& co., 1974), 1935; Samson, "Zur Geschichte und Symbolik der Glocken," 356; Kurt Kramer, Die Glocke: Eine Kulturgeschichte (Kevelaer: Butzon \& Bercker, 2012), 8; Percival Price, Bells and Man (Oxford: Oxford University Press, 1983).

12 R. Murray Schafer, The Soundscape: Our Sonic Environment and the Tuning of the World (Rochester, vT: Destiny, 1994 [originally published in 1977 under the title The Tuning of the World]), 49. See also the introduction to Reinhard Strohm, Music in Late Medieval Bruges (Oxford: Clarendon, 1990), 3-4.

13 Schafer, The Soundscape, 54. 
significant features of these settlements. ${ }^{14}$ According to art historian Gauvin Alexander Bailey, by 1512, the Laws of Burgos had stipulated that Spanish encomenderos had to "provide their charges with a church with a bell [and] images of our Lady."15 And, in a letter of 1615, the Jesuit Roque González de Santa Cruz (1576-1628) recalls how a new mission settlement in Itapúa was started: a bell was pealed and a cross raised. ${ }^{16}$

It becomes clear that in the mission settlements bells were hung very deliberately, with an obvious sense of their supposed anti-pagan power and as a "civilizing" medium. Through bells, the only mass medium available, the missionaries communicated with the residents, called everybody to prayer, church, or work, and installed European time patterns. The sounds also made Europeans feel more at home. As in Europe, bells were supposed to do apotropaic work by chasing away demons, but in the mission contexts they acquired an added layer of acoustic significance: they established a new, common, and Christian soundscape, superimposed on the pagan one. Bells made the acoustic hegemony of the Christians audible to all, whether they wanted to listen or not. Ultimately, bells as the loudest, most obvious, and longest-lasting feature of acoustic hegemony can be seen as potentially achieving the final sonic goal of any missionary: "to hear on all sides the praises of the Creator resounding in those barbarous countries."17

Every reducción among Guaraní-speaking people had a bell tower with a bell. The missionary Anton Sepp (1655-1733) wrote in 1698 that "each canton has a very handsome lofty built Church and Steeple, with 4 or 5 bells." 18 The famous Brabo inventories, which document the status quo immediately after the expulsion of the Jesuits in 1767 , list bells for every single reducción

14 Gauvin Alexander Bailey, Art on the Jesuit Missions in Asia and Latin America, 1542-1773 (Toronto: University of Toronto Press, 2001), 35 .

15 Ibid.

16 Clement J. McNaspy, S.J., Conquistador without Sword: The Life of Roque González, S.J. (Chicago: Loyola University Press, 1984), 111.

17 Appendix to Ludovico Antonio Muratori's Cristianesimo felice, in Ludovico Antonio Muratori, A Relation of the Missions of Paraguay, Wrote Originally in Italian, by Mr. Muratori, and Now Done into English from the French Translation (London: Marmaduke, 1759), 257.

18 Anton Sepp, An Account of a Voyage from Spain to Paraquaria: Performed by the Reverend Fathers Anthony Sepp and Anthony Behme, Containing a Description of All the Remarkable Things and the Inhabitants, as Well as of Missionaries Residing in That Country; Taken from Letters of the Said Anthony Sepp; And Publish'd by His Own Brother Gabriel Sepp; Translated from the High Dutch Original, Published at Nuremberg, 1697 (London: Churchill, 1704), 658 . 
and refer to several villages where bells could be cast. ${ }^{19}$ In the early days, bells were imported, but soon they were cast in situ as part of a bundle of trades, as mentioned in the continuation of Sepp's text: "[the missionaries] taught these poor Wretches the Rudiments of the Christian Religion, to say Our Father, to bake Bread, to Paint, cast Bells, Organs and Trumpets." ${ }^{20}$ In another book from 1714, Sepp notes that the Guaraní "cast the metal into bells with a sound as light as those of Nola in Campania"; 21 this reference is particularly remarkable because, in contrast to bread baking and praying, the casting of bells was definitely not a daily activity.

\section{The Conquista espiritual of Montoya}

In what follows, I will take the Conquista espiritual of Antonio Ruiz de Montoya $\left(15^{8} 5^{-1652)}\right.$ as my main source. ${ }^{22}$ The Jesuit Montoya, a Lima-born son of a Spanish father and a (probably) indigenous mother, took part in the establishment of the very first Jesuit reducciones among Guaraní-speaking peoples (around 1610) in the region of the upper Paraná river. ${ }^{23}$ In 1622,

19 "Lo que se usa en la Oficina de fundir Campanas: Primeram ${ }^{\text {te }}$ Un Punson, una cuchara de hierro. It. Torno, y dos Escoplos, tres Cinceles, y dos barretas pequeñas de hierro en que hacen los moldes de Campanitas pequeñas." Quoted in Francisco Curt Lange, "El extrañamiento de la Compañía de Jesús del Río de la Plata (1767): Documentos," Revista Musical Chilena 165 (1986): 4-58, here 39.

20 Sepp, An Account of a Voyage from Spain to Paraquaria, 658.

21 "Sie giessen das metall zu glokhen so hellshallend als zu Nola in Campania": Esther Schmid Heer, ed., Anton Sepp sJ (1655-1733) - Paraquarischer Blumengarten: Ein Bericht aus den südamerikanischen Jesuitenmissionen (Regensburg: Schnell und Steiner, 2011), 191. On the fabrication of musical instruments in the reducciones and musical life in general, see Bernardo Illari, "El sonido de la misión: Práctica de ejecución e identidad en las reducciones de la provincia del Paraguay," in Música colonial Iberoamericana: Interpretaciones en torno a la práctica de ejecución y ejecución de la práctica, ed. Victor Rondon (Santa Cruz de la Sierra: APAC, 2004); Johann Herczog, Orfeo nelle Indie: I gesuiti e la musica in Paraguay (1609-1767) (Lecce: Congedo, 2001); and the many writings by Leonardo Waisman.

22 Antonio Ruiz de Montoya, Conquista espiritual hecha por los religiosos de la Compañía de Jesús en las provincias del Paraguay, Paraná, Uruguay y Tape (Madrid: En la imprenta del Reyno, 1639). Here I quote from the 1892 edition. An English revised edition of this text is forthcoming from the Institute of Jesuit Sources at Boston College in 2017.

23 For historical facts and demographic data, see Julia J.S. Sarreal, The Guaraní and Their Missions: A Socioeconomic History (Stanford: Stanford University Press, 2014), Appendix one. 
he became superior of the missions of Guayrá, and in 1638, superior of all mission activities in the province of Paraguay. In this function, he travelled to Spain for political reasons, where he had several books printed, among them the Conquista espiritual (1639). ${ }^{24}$ This first chronicle of the Guaraní missions printed in Europe is a pioneering example of the missionaries' approach to the New World. It is of a mixed style, combining the down-to-earth reporting of the cartas anuas ${ }^{25}$ with reportage on the current state of the missions and a chronicler's narration of people, places, and stories. ${ }^{26}$ In addition, the book is not as impersonal or objective as it could have been; Montoya takes care to present himself as a model missionary, as well as recounting his visions and spiritual experiences. As he himself confirms in a letter, the chronicle was assembled and written for Spanish eyes and ears, and on behalf of the authorities, especially the oidor de Indias and newly elected bishop of Puebla de los Angeles, Juan de Palafox y Mendoza (1600-59). ${ }^{27}$ Given the absence of any indigenous testimonials from the period, the Conquista espiritual is among the closest modern readers can get to the contemporary views and beliefs of the Guaraní. ${ }^{28}$ It presents a Jesuit's version of a few (and precious) indigenous rites, rituals and convictions, obviously mediated many times, through many layers of cultural translation. ${ }^{29}$

In the Conquista espiritual, allusions to bells are frequent. Montoya mentions them as objects of religious desire and veneration, and as a subject of

24 The others were a dictionary, a phrasebook, and a catechism in Guaraní: see Jimena Ferreiro Hormazábal, "Antonio Ruiz de Montoya, misionero y místico: Los variados caminos de la fe en el Virreinato Peruano (siglo XVII)," Diálogo andino 33 (2009): 43-581; José Antonio Rouillón Arróspide, S.J., Antonio Ruiz de Montoya y las reducciones del Paraguay (Asunción: Centro de Estudios Paraguayos Antonio Guasch, 1997), 9o; Ernesto Maeder, "La Conquista espiritual de Montoya y su alegato sobre las misiones," Teología: Revista de la Facultad de Teología de la Pontificia Universidad Católica Argentina 46, no. 1 (1985): 126-27; Louis Necker, Indiens Guarani et chamanes franciscains: Les premières réductions du Paraguay (1580-180o) (Paris: Anthropos, 1979), 117.

25 See for example Markus Friedrich, "Circulating and Compiling the litterae annuae: Towards a History of the Jesuit System of Communication," Archivum historicum Societatis Iesu 77 (2008): 3-40.

26 Maeder, "La Conquista espiritual," 135.

27 "El Señor don Juan de Palafox, con ser electo y publicado obispo de la Puebla de los Angeles, y hasta ahora Oidor de Indias, me pidió escribiese algo de esa Provincia." Letter by Montoya (c.1640), in Maeder, "La Conquista espiritual," 125-26.

28 See Schmid Heer, Paraquarischer Blumengarten, 40.

29 See Barbara Ganson, "Antonio Ruiz de Montoya, Apostle of the Guaraní," Journal of Jesuit Studies 3, no. 2 (2016): 197-210 (doi: 10.1163/22141332-00302002). 
dispute between different factions. He recounts sending several fathers to the lands of the Itatínes, during the forced exodus-like relocation of several reducciones in the 1630s. In that enterprise, the missionaries took bells, pictures, and other heavy objects along with them on their boats. ${ }^{30}$ A testimony from 1828 , during a forced relocation in the post-Jesuit period, describes how the group of Guaraní in a procession, with musicians and all, carried santos and santitos - big and small statues of saints—-with them, and dragged bells along on wagons. ${ }^{31}$

One story in Montoya's chronicle depicts a bell as a prized possession of the community and as a point of contention between divine and demonic, Christian, and non-Christian forces. While working to cover the top of a belfry (cubriendo un campanario), the missionary suddenly starts to fear that one of the indigenous workers might fall and die without the last rites, or that lightening will strike and destroy bell and church. Eventually, he turns to the Sacrament - which had already been put in place (que ya lo habiamos colocado — and pleads with the Lord: if anything had to happen, he would rather recast the bell than see a worker die without confession. The story continues:

The bell was pealed various times on that particular day, and at night for the Ave Maria and afterwards for the animas; on the next day, when it was pealed for the first time, we could hear that it had broken: the loss consoled me greatly (even though [the bell] was highly estimated in this area) because it meant the gain of an Indio. ${ }^{32}$

"Llevaron consigo campanas, imágenes y otras cosas, que su peso impidió encaminarlas por tierra." Antonio Ruiz de Montoya, Conquista espiritual hecha por los religiosos de la Compañía de Jesús en las provincias del Paraguay, Paraná, Uruguay y Tape (Bilbao: Imprenta del Corazón de Jesús, 1892), 159.

"Cada reducción o tribu marchaba como en procesión, presidida por los ancianos que llevaban los santos principales. El pueblo conducía multitud de santitos. A la cabeza de aquellos iba la música. Cada tribu tenía la suya, compuesta de violines. Los músicos son también los cantores [...] llevaban objetos del culto y hasta campanas." Quoted in Guillermo Wilde, Religión y poder en las misiones de Guaraníes (Buenos Aires: Editorial Sb, 2009), 373 .

“Tocóse varias veces la campana aquel dia, y á la noche al Ave María y despues á las ánimas; el día siguiente al primer toque que se dió con ella la sentimos quebrada: consolóme mucho su pérdida (si bien era de mucha estima en aquellas partes) por la ganancia del indio": Montoya, Conquista espiritual, 79 . 
A few hours later, the missionary recounts, a colleague from the next reducción sends a letter asking if the bell is really broken-he claims that the devil has shown himself to a group of indigenous people there and uttered clear and provocative words: "Marvel at my power, I have just broken the bell of Loreto." ${ }^{33}$ Montoya answers the colleague telling him his side of the story, and confirming that the "father of lies" this time told the truth: the devil did indeed break the bell, but did not notice that it was an orchestrated plot in order to prevent something even worse. The Lord-through the mediation of the missionary - thus utilized and finally outwitted the devil, at least according to Montoya. The missionary even claims to have played an active role in shaping fate, in that he avoided the looming death of an indigenous worker by sacrificing a prized bell. The cracked bell thus turns into an asset, and the evil intentions of the devil are brought to nothing.

This story is not only a fine example of how different interpretations-supposed demonic and divine interventions, with a missionary in betweencould be found for the very simple circumstance of a cracked bell. It is also important because it reveals what kind of weapons were attributed to the devil: he is cited for his power to define the soundscape, to retain the old and to fight attempts to establish the new. Obviously, the devil often broke bells: many medieval legends and images feature him destroying these sonic symbols of Christianity. Gregory the Great's (540-604, r.590-604) Vita Benedicti narrates Saint Benedict's isolation in a cave: the daily ration of bread brought to him is announced by a little bell tied to a rope, which the devil eventually targets for destruction.

Another tale, situated in the Valais, recounts how Bishop Theodul allows the devil to carry him from Rome to his hometown in an upside-down bell, until the enraged devil throws it to the ground where it breaks into pieces and sinks. It reemerges and starts to peal at the bishop's summons. ${ }^{34}$

Ernest Morris reports a similar English story in which the "archfiend" carries off bells that are out of use. The devil disappears with them into a boggy pool, but "notwithstanding the aversion of the powers of darkness to such sounds, even these bells are sometimes permitted to favour their native place with a ghostly peal." ${ }^{35}$ Bells and their sounds definitely annoy the devil and he cannot

"Mirad mi poder, yo vengo ahora de quebrar la campana de Loreto": Montoya, Conquista espiritual, 79 .

34 Kramer, Die Glocke, 43 .

35 Morris, Legends o' the Bells, 68. 
keep them from pealing; but at the same time, the message of the bells is not entirely unambiguous.

\section{The Martyrs}

The Conquista espiritual ends with the 1628 killing of Montoya's fellow Jesuits Roque González de Santa Cruz and Alonso Rodríguez (1598-1628); the two missionaries had set out to establish a new reducción (in what is today southwestern Brazil, in the state of Rio Grande do Sul), named Todos los Santos del Caaró after the twenty-six Christians who had been martyred in Nagasaki in 1597 and beatified in $1627 .{ }^{36}$

Here, a bell figures as the last object touched by a Jesuit killed while working to make it sound for the first time in "barbarous countries." Juan Eusebio Nieremberg's (1595-1658) Historia panegyrica from 1631, the oldest printed source on the martyrdom, reports the following: "Father Roque had summoned the Indians on 15 November to assemble, so that he, with greater solemnity, could lift the bell, and its ringing could announce the hour for explaining the Christian doctrine." 37 Then, immediately before his death, "Father Roque went happily out to the Indians in order to hang the bell. He bent to attach a rope to the tongue of the bell for ease of ringing. He said, 'My children, soon you will hear that you are called to listen to heavenly doctrine."'38 Montoya writes that Roque "with his own hands wanted to tie the clapper to a bell, something

36 Rafael Carbonell y Masy, "Un anciano cacique guaraní unido al martirio de los santos Roque González de Santa Cruz y de Alonso Rodríguez, sJ," in Educación y evangelización: La experiencia de un mundo mejor, ed. Carlos E. Page (Córdoba, Argentina: Universidad Católica Argentina, 2005), 81.

37 "Condixerat P. Rochus conventuris Indis decimam quintam Novembris diem, ut solemnius elevaret campanam, cuius pulsu explicaret horam declarandae Christianae doctrinae." Juan Eusebio Nieremberg, Historia panegyrica de tribus gloriosis martyribus, ex eadem Societate Iesu, nuper in Urugai pro fide occisi, quorum martyry gloriam multa prodigia significarunt (Lyon: Cardon, 1631), 18.

38 "Exiit enim laetissime P. Rochus, peracto sacrificio, actis devotissime gratiis, ad Indos, \& campanam adornandam; inclinavit se, ut funem obligaret lingulae ad aptitudinem pulsus; dicebat: Filij, brevissime audietis citari vos ad doctrinam caeli": Nieremberg, Historia panegyrica, 20. English translation from Primeras noticias de los protomártires de Paraquaria: La "Historia panegírica" de Juan Eusebio Nieremberg, ed. W. Michael Mathes (Carem: Casa de la Cultura, 2004), 92-93. 
never seen before by this barbarous people, in order to adorn the feast with its sound." 39

In all accounts, the murderer takes advantage of the missionary's position (bent over the bell) and shatters Roque's skull with a club. ${ }^{40}$ Immediately afterwards, Alonso Rodríguez is killed just as he leaves his hut. In a contemporary engraving by Abraham van Diepenbeeck (1596-1675), both murders take place simultaneously. Alonso Rodríguez is shown being beaten to death while reading a book, which must have been the Bible. Fundamentally, both Jesuits are killed in the moment before the missionizing begins: before Rodríguez starts to announce the word of God by reading the Bible out aloud, and before Roque González starts to propagate the sound of God in the pealing of the bell. Canonized in 1988, Saint Roque is often figured holding his intact heart-and with a bell beneath his feet.

It is obvious that the murderer kept Roque from ringing the bell for the very first time, even though the indigenous people pictured could not have known what a bell was. They could not be aware that the quest for acoustic hegemony was now commencing. Montoya constructs the story as a black-and-white narrative: he calls the cacique Necu, the presumed instigator of the killings, a slave of the devil, and describes the indigenous murderers as vile and malicious killers who take advantage of the missionaries' ingenuousness. And he constructs the story as if it were about a bell: it is not only that Roque González embodies the bell, but the martyr's soul ascends into heaven "con repique de campana" - with the ringing of bells. ${ }^{41}$ Here, the fight for acoustic hegemony through bells is encapsulated in a story of martyrdom, ${ }^{42}$ in which, incidentally, the sound of bells is seen as appealing not only to Christians, but also to potential converts. The Jesuits were certain that indigenous non-Christians would be lured to church through the new sound, rather than driven away. ${ }^{43}$ As the

39 "Por sus propias manos quiso atar la lenguëta á una campana, cosa nunca vista de aquella gente bárbara, para con su sonido regocijar la fiesta”: Montoya, Conquista espiritual, 230.

40 Nicolás del Techo describes the situation very clearly: "ad obligandam fune campanae lingulam se inclinaverat": Nicolás del Techo, Historiae provinciae Paraquariae Societatis Jesu (Liège: Hovius, 1673), 221.

41 "Levantó este vil esclavo del demonio [...] una porra de armas [...] y dando al Padre un furioso golpe en el cerebro le hizo pedazos la cabeza, con que á golpes y repique de campana voló su alma regocijada al cielo." Montoya, Conquista espiritual, 230.

42 See McNaspy, Conquistador without Sword, 147-91.

43 Heinrich Samson reports a medieval story in which bells are employed as media of acoustic warfare. The non-Christians occupying a town flee when the bells are rung. Samson, "Zur Geschichte und Symbolik der Glocken," 335. 
contemporary Roman scholar Angelo Rocca writes, bells are rung "so that all listeners may take refuge in the arms of the Holy Church."44

\section{Material Culture}

Nowadays, the Capilla de los Mártires in the Colegio del Cristo Rey in Asunción, Paraguay, preserves Saint Roque's intact heart and the club with which he was killed, ${ }^{45}$ although not the relics of the bell, which Montoya's narrative claims were held there ("hoy tenemos esta campana por reliquia"). ${ }^{46}$ But Montoya does assert that parts of the bell had been used to make arrow heads, so the account turns into a story about material culture and the reinterpretation of sacred objects. Indigenous people recycled the metal used for the bell, so the material of the bell, the powerful acoustic symbol of Christianity with apotropaic powers, becomes paganized and can now be used against the Christians. Likewise, at another point in the Conquista espiritual Montoya mentions the crucial arrows and arrowheads and the reinterpretation of material used for them: "Instead of sharpening human bones for their arrows, they already worked on crosses to wear around their necks." 47

A similar bell story from the Jesuit mission context including the recycling of metal is told by Anton Sepp, a fellow Tyrolean Jesuit. In his famous and widely read Reisbeschreibung, a travel report and chronicle of the reducciones (published in German in 1696), ${ }^{48}$ Sepp mentions a little bell and its apotropaic power used during the crossing of the ocean:

Our procurator had brought along with him a Sanctify'd Bell as we call it, and Kaloke by the Americans, unto which they attribute this Vertue, that as far as its Sound reaches, no Thunder or Lightning can do any Mischief; for which reason we took care to have it rung at this time of Danger. The Original of its Vertue must be traced as far as Mexico, where they say, was formerly a Bell of a vast Bulk, which as often as it Lightned and Thundred, rung of it self, and as far as the Sound thereof reached, no Thunder-bolt

\footnotetext{
44 "Ut audientes confugiant ad Sanctae matris Ecclesiae gremium." Rocca, De campanis, 43.

45 See www.jesuitas.org.py.

46 Montoya, Conquista espiritual, 280.

47 "En lugar de aguzar huesos humanos para sus saetas, ya labraban cruces para traer al cuello": Montoya, Conquista espiritual, 141.

48 Anton Sepp, RR.PP. Antonii Sepp, und Antonii Böhm Reisbeschreibung wie dieselbe aus Hispanien in Paraquariam kommen (Nuremberg: In Verlegung Johann Hoffmanns, 1698).
} 
was ever known to fall; afterwards it was thought fit, to cast many Bells of the Mettal of this great Bell, which are given as a singular Present to Persons of Quality; and ours is one of the same kind, every Procurator who goes from the Indies to Rome, having such a Bell allowed him, to protect him in his Voyage. ${ }^{49}$

It is important to note that the English translation differs from the original German, quoted here in the footnote: in the English version, the bell does ring of itself, but not from under the earth as in the German original. Also, there is no question whether the bell was brought from heaven by angels, as Sepp wonders in the German original ("ist unbewußt / ob die Heiligen Engel solche vom Himmel gebracht"). In English, the legend of the origin of the bell is attributed to someone else ("where they say"); while in German Sepp says "it had been heard in Mexico."

It is obvious that the missionaries knew all the legends of bells which peal of themselves, submerged or hidden; ${ }^{50}$ here, they applied them to the unfamiliar circumstances of the New World. It is difficult to say if and to what extent indigenous knowledge is reflected here, but it seems to be a quintessentially Jesuit story of adaptation, applied to material culture: the mysterious, miraculous big bell is fused in order to make plenty of small bells. Like the case of the arrowheads made from bell metal, the bell's power is transferred to many little bells: again, the bell is treated like a relic, as with the fatal bell of Roque González.

Bells, whose sounds can stand for war and religion at the same timeas implied by Schafer-were a central instrument in the Jesuit missions of

49 English version from Sepp, An Account of a Voyage from Spain to Paraquaria, 638-39. Compare the German version, from Sepp, Reisbeschreibung, 41-43: "Unser Procurator hatte ein kleines Sanctus-Glöcklein/ so man Kaloko nennet/ bey sich/ dieses vermag wider das ungestümme Wetter so viel/ daß/ so weit sein Hall und Klang sich erstrecket/ und gehöret wird/ keine Donner-Keule fallen. Dero Ursachen/ gleich da es anfängt zu blitzen/ läuten wir dieses Glöcklein/ und seynd sicher von aller Gefahr. Seine Krafft kommt daher. In Mexico war nicht unlängst eine überaus grosse Glocken/ so sich selber läutete/ unter der Erden gehöret worden: Ist unbewußt/ ob die Heiligen Engel solche vom Himmel gebracht/ so offt nun der zornige Himmel mit einem hohen Wetter der Stadt und denen Innwohnern droht/ fänget solche gleich an sich selbst zu läuten: Und so weit dero Schall gehöret wird/ ist biß dato kein Stein gefallen. Nach dem hat man unterschiedliche kleine Glöcklein aus diesem Metall gegossen/ selbige zu mehrern Nutzen hin und wieder hohen Stands-Personen verehret. Dergleichen dann ware das unserige/ so alle Procuratores, die von Indien über das Meer nacher Rom schiffen/ zu sich zu nehmen pflegen.”

See Morris, Legends o' the Bells. 
Paracuaria. The idea that bells stood for the idée fixe of making the whole world listen inscribes itself seamlessly into the mission context treated here. Bells thus served many different purposes - as a very obvious sign of Christianity, as venerated objects, as subjects of acoustic battles of authority with the devil and even as relics - but, most importantly, that of promoting acoustic hegemony. 